\title{
Optimization of BAZNAS Programs on Sustainable Development Goals (SDGs): Analytic Network Process Approach (ANP)
}

\author{
Mohamad Handi Khalifah \\ University of Indonesia \\ Mohammad Soleh Nurzaman ${ }^{1}$ \\ University of Indonesia \\ Muhammad Cholil Nafis \\ University of Indonesia
}

\begin{abstract}
With the release of the United Nations (UN) Sustainable Development Goals (SDGs) program, the Government of Indonesia (BAPPENAS) is committed to realizing Sustainable Development Goals (SDG) in Indonesia. The essence of the spirit of Islam in solving poverty is the inclusive nature that must be attached to the development of Islamic finance and related to issues of poverty alleviation as a basic responsibility in achieving the goals of Shari'ah (al maqashid Shari'ah). In realizing Sustainable Development Goals (SDGs), it will require Zakat Organizational Programs. The purpose of this study is to measure the priority scale of the 7 Grand Programs of BAZNAS on 17 Goals of Sustainable Development Goals (SDGs). This research uses Analytical Network Process (ANP) method, wherein the process performs pairwise comparison and uses super matrix calculations to measure the interrelationship between the elements. The results of the measurements by Analytical Network Process (ANP) and statistics show some of the priority conclusions which include Pillars of Environmental Development (W= 0.47783), Partnership for All Development Objectives $(W=0.00486)$ and Zakat Community Development $(W=0.07367)$.
\end{abstract}

Keywords: Zakat Program, Sustainable Development Goals, Optimization, Development

\section{INTRODUCTION}

After the end of the Millennium Development Goals (MDGs) by the end of 2015, the United Nations (UN) released a new program called Sustainable Development Goals (SDGs). The program of development planning was compiled in the document "Transforming Our World: The 2030 Agenda for Sustainable Development". This document contains 17 goals and 169 development targets to overcome underdevelopment in a comprehensive sense for developing countries around the world (Hoelman, 2015). In response, the Indonesian government has been committed to implementing these Sustainable Development Goals.

Waage (2015) states that the problems of modern society in improving public facilities require a well-structured solution in the form of long-term programs for realizing the welfare objectives.

In the development of Zakat institutions, both in Indonesia and internationally, there is no standard measure to evaluate the performance of Zakat in aggregate. This means that we need to assess the progress of Zakat by using a comprehensive indicator. Such 
indicators should capture the macro dimensions such as government support in terms of arrangements and budgets, Zakat databases, as well as the micro dimensions that assess the performance of Zakat management and the impact of Zakat to mustahik (Nurzaman, 2017).

Ahmed (2015) stresses that Islamic finance has a strong potential in promoting financial stability, financial inclusion and shared prosperity and infrastructure development that will create an environment that supports the implementation of Sustainable Development Goals (SDGs).

Zakat has an important economic function to alleviate poverty. Furthermore, Zakat has significant effects on the macroeconomy. But in reality, Zakat's economic function has not been optimal in alleviating poverty due to less professional management (Norvadewi, 2012). Sustainable Development Goals (SDG) are expected to provide new solutions for the implementation of 7 Grand BAZNAS Programs.

According to Kahf (1999), the main purpose of Zakat is to achieve social and economic justice. Zakat is a simple transfer of a prescribed portion of the wealth of the rich to be allocated to the poor. Thus, the mobilization of Zakat has the potential to contribute through various programs to help in meeting the welfare objectives. Therefore, Zakat can contribute positively towards achieving the Sustainable Development Goals (SDGs)

Based on the research of The National Board of Zakat (BAZNAS), the potential of national Zakat in 2015 reached Rp 286 trillion (2.4\% of GDP in 2015). This figure is generated using an extrapolation method that considers GDP growth in previous years as illustrated in Table 1.

Table 1. Number of ZIS Collection in Indonesia (Year 2002 - 2015)

\begin{tabular}{|c|c|c|c|c|}
\hline Year & $\begin{array}{c}\text { Rupiah } \\
\text { (Billion) }\end{array}$ & USD $^{\mathbf{2}}$ (Million) & Growth (\%) & $\begin{array}{c}\text { GDP Growth } \\
(\boldsymbol{\%})\end{array}$ \\
\hline 2002 & 68.39 & 4,98 & - & 3,7 \\
\hline 2003 & 85.28 & 6,21 & 24,70 & 4,1 \\
\hline 2004 & 150.09 & 10,92 & 76,00 & 5,1 \\
\hline 2005 & 295.52 & 21,51 & 96,90 & 5,7 \\
\hline 2006 & 373.17 & 27,16 & 26,28 & 5.5 \\
\hline 2007 & 740 & 53,86 & 98,30 & 6,3 \\
\hline 2008 & 920 & 66,96 & 24,32 & 6,2 \\
\hline 2009 & 1200 & 87,34 & 30,43 & 4,9 \\
\hline 2010 & 1500 & 109,17 & 25,00 & 6,1 \\
\hline 2011 & 1729 & 125,84 & 15,30 & 6,5 \\
\hline 2012 & 2200 & 160,12 & 27,24 & 6,23 \\
\hline 2013 & 2700 & 196,51 & 22,73 & 5,78 \\
\hline 2014 & 3300 & 240,17 & 22,22 & 5,02 \\
\hline 2015 & 3700 & 269,29 & 21,21 & 4,79 \\
\hline
\end{tabular}

Source: (BAZNAS, 2016). 
As part of the Islamic economic elements, Zakat has a very important role in economic growth in Indonesia. The role of Zakat institutions in the economic activities of Indonesia is not less important than the function of any other Islamic financial institutions. The existence of existing Zakat institutions is expected to stimulate the economy of a country. The purpose of zakat institutions in the Indonesian economy is expected to be a stimulus factor for Indonesia ${ }^{\text {ee }}$ economic prosperity in decisively reducing poverty levels, creating economic justice, creating equitable income distribution and promoting social security with effective services.

Lawal (2016) concludes that although with the introduction of Sustainable Development Goals (SDGs), it will reduce the problem to a minimum, this success can only be achieved fully with the help of Islamic finance as it has some built-in features that conform to standards. The Sustainable Development Goals (SDGs) are a global and national commitment in efforts to improve the welfare of the community through covering the 17 development goals.

Figure 1. Availability of SDGs Indicators in Indonesia by Pillar

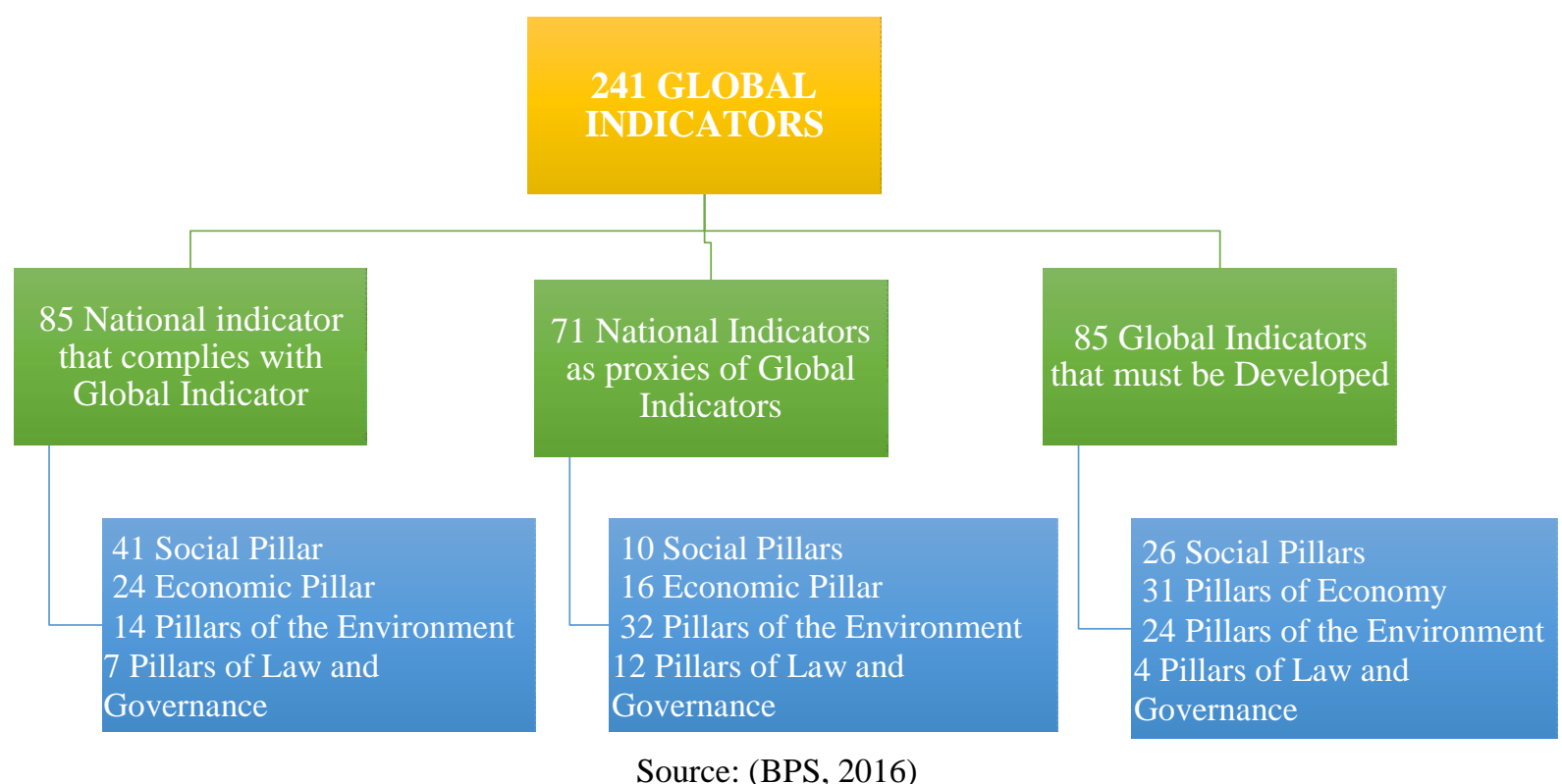

The Government of Indonesia has committed itself to becoming a leading pioneer and role model in achieving Sustainable Development Goals (SDGs). Sustainable Development Goals (SDGs) also expand funding sources not only from the developed countries but also from the private sector. Furthermore, Sustainable Development Goals (SDGs) emphasize human rights to ensure that there is no discrimination in the effort to eradicate poverty in all its forms. Sustainable Development Goals (SDGs) apply an inclusive principle involving all parties from the government, civil society, philanthropists, businesses, and the academia. One very ambitious target of the Sustainable Development Goals (SDGs) is that MDGs target only "half", but SDGs target achievement of indicators at the "zero" levels. Sustainable Development Goals (SDGs) do not only include the purpose, but also the means of implementation to ensure that all goals are achieved (BAPPENAS., 2017). 
Figure 2. Participation Platform \& Principles of SDGs

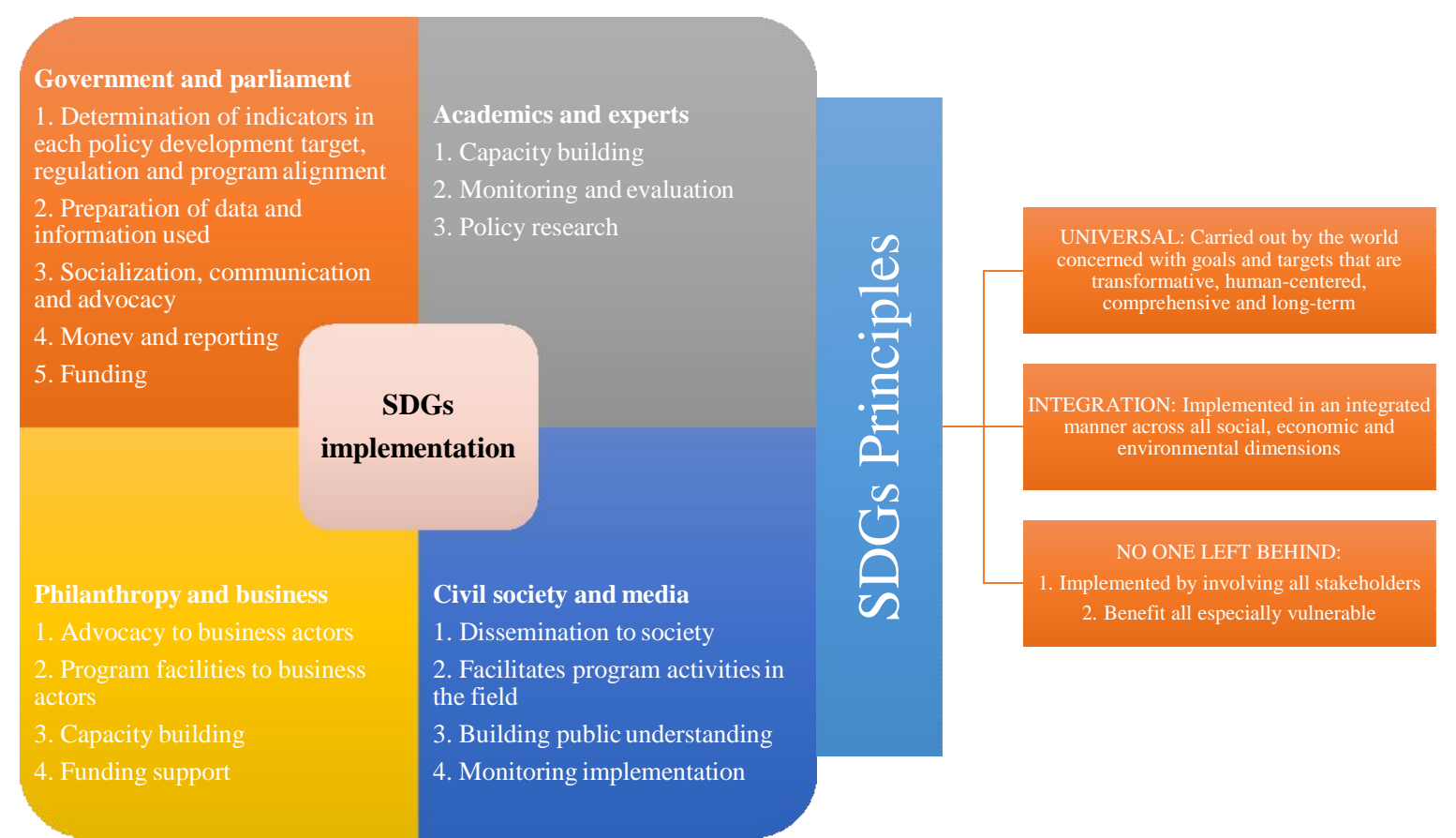

Source: (BAPPENAS., 2017)

In this setting, the most important task of Muslim intellectuals, politicians, economists, and policymakers is to turn the Zakat institution into a practical philanthropic movement that will foster a culture of cooperation and social justice. As a result, it will enhance the process of economic growth and prosperity throughout the Muslim world.

The Muslim government must form an advanced philanthropic organization and give it whatever support it needs. In a Muslim society, the practice of Zakat evasion is tantamount to promoting corruption and reducing development. Therefore, efficient management of Zakat, from collection to the distribution level, in such situations is the primary responsibility of governments, civil society, and every Muslim individual to contribute to a just division of wealth so that the weakest part of the society can be strengthened and becomes elevated to a level whereby the basic needs are met. (Malik, 2016).

In this context, if Zakat can be managed in an effective way by involving global programs, then it becomes a promising solution to the problem of poverty alleviation, especially in Muslim countries. In many Muslim countries, the Zakat collection program is slightly more efficient than the Zakat distribution program due to the lack of program mechanisms to ensure sustainable benefits for beneficiaries. This effort is a challenge when combined with the context of today"s complex economic situation, where Zakat managing regulators are required to find an efficient way of managing Zakat for the growth and prosperity of society, compared to the 
situation when Zakat was first introduced in Islam.

Based on the above explanations, the opportunity presents itself also as a challenge for The National Board of Zakat (BAZNAS) to further optimize the rolling program, by combining the additional reference framework for pursuing the Sustainable Development Goals (SDGs).

\section{LITERATURE REVIEW}

It is undeniable that society is always evolving and changing with culture, thinking and so on. Therefore, in maintaining the development and change, there is a need to apply the Zakat rule in light of the Islamic concept of Siasah alShari'ah which emphasizes the application of all Islamic principles based on Qiyas doctrine (analogy) and Masalih alMursalah (Public interest). Such a measure is necessary to ensure the successful implementation of Islamic Zakat regulations based on the doctrine of Siasah al-Shari"ah (Billah, 2016).

Various tools and concepts which support the creation of sustainable development and offer solutions to a wide range of growing problems should be utilized. The overall understanding of sustainable development in the Islamic context has much in common with how they are understood in the mainstream literature, especially with regard to intergenerational equity and quality of life improvement (Kamali, 2016). Nouh (n.d) argues that the goal of sustainable development is linked and in line with Islamic objectives that call for avoiding waste, monopoly, corruption, promoting reform and rationalization of natural resources. The motivation for sustainable development is also reinforced by the Qur'anic verse:
The five characteristics of development include (1) Comprehensive, (2) Human development, (3) A balanced economy, (4) Quality change, and (5) Distribution resource fairness (Sadeq, 2006).

Therefore, it is important for Muslim governments to restructure their spending in a feasible way, not only reduce their overall expenditure but also to concentrate more on projects that will help to accelerate development and realize the Maqasid Shariecah (Chapra, 1992). Since the concept of sustainable development is a concept of development that has an optimum target achievement in view; hence, the value that is put forward is not only concerned with the present generation, but with far ahead. The concept encourages the emergence of the concept of sustainable management (Hadad, 2015).

Sadiq (2015) states that sustainable development is a concept that combines "the needs of the present generation without diminishing the ability of the future generations to meet their own needs". The core achievement of this vision lies in three things: economic growth, social inclusion, and environmental protection. (Kamali, 2016). Islamic finance plays an important role in the first two aspects. Other models view the environment (natural capital) as the overall foundation of life support system for the inhabitants of the planet.

Furthermore, BAPPENAS, (2017) states that Sustainable Development Goals (SDGs) are development goals that focus on improving the sustainable economic prosperity of the people, social community life, quality of the environment and ensures fairness and implementation of governance that is capable of maintaining the quality of life from one generation to the next.

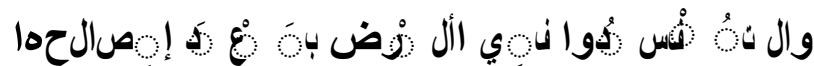

"... Do not make mischief in the earth after

God has mended it" (al-A'raf Verse 85) 


\section{RESEARCH METHODOLOGY}

Analytic Network Process or ANP is a general theory of relative measurement used to derive a composite priority ratio from an individual ratio scale reflecting relative measurements of the effects of interacting elements with respect to control criteria (Saaty, 1999).

Analytic Network Process (ANP) is a mathematical theory that allows one to deal systematically with dependencies and feedback. ANP captures the effect of feedback and interaction among all elements. It is assumed that there is no such feedback on hierarchical models, such as Analytic Hierarchy Process (AHP). Therefore, AHP is a special case of ANP (Azis, 2003).

Analytic Network Process or ANP is a new approach of qualitative, nonparametric and non-bayesian methods for a decision-making process that provides a common framework for treating decisions without making assumptions about the independence of elements.

Figure 3. Differences Linear Hierarchy and Feedback Network

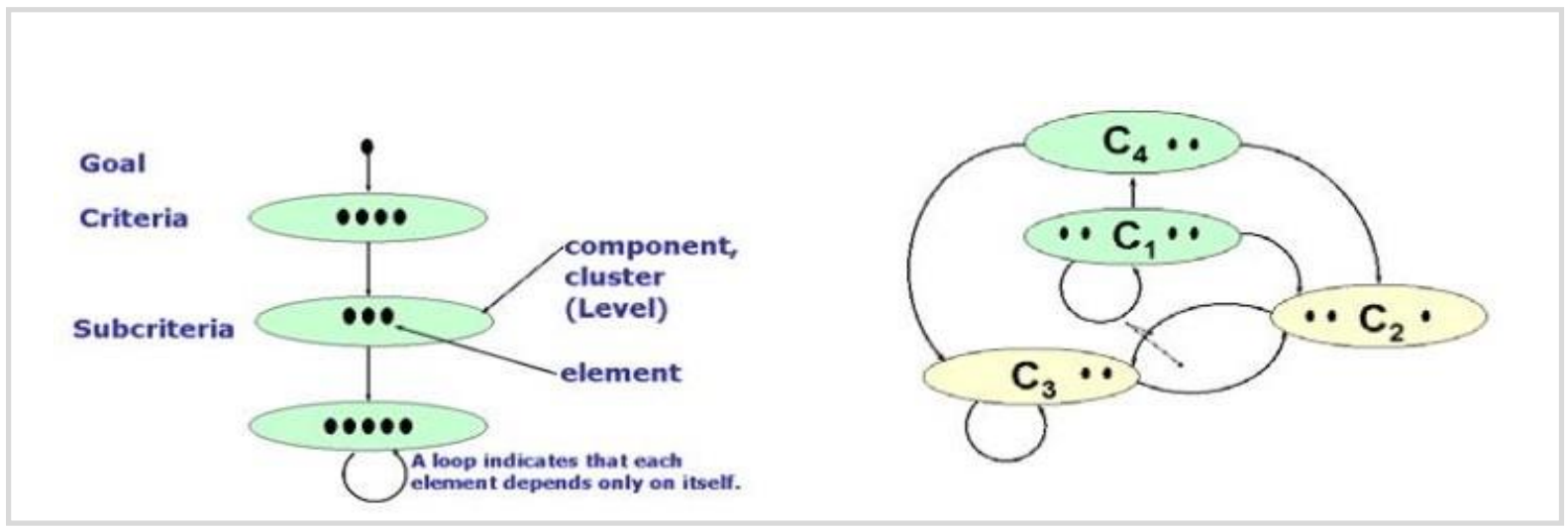

Source: (Azis, 2003)

Analytic Network Process (ANP) is a combination of two parts. The first part consists of a control or network hierarchy of criteria and sub-criteria that controls interactions. The second part is the network of influences between elements and clusters (Ascarya, 2015). In the ANP method, the number of respondents is not important. The most important element is that the selected respondent is the person who is competent and an expert in the field.
The Analytic Network Process (ANP) Questionnaire is presented in the form of pairwise comparison between elements in the cluster to see the comparison and magnitude of influence. The scale used is a numerical scale of 1-9 to translate verbal judgments.

Ascarya (2005) suggests that the basic principles of AHP / ANP are three, namely decomposition, comparative judgments, and hierarchical or synthesis composition of priority. 
Figure 4. ANP Research Stage

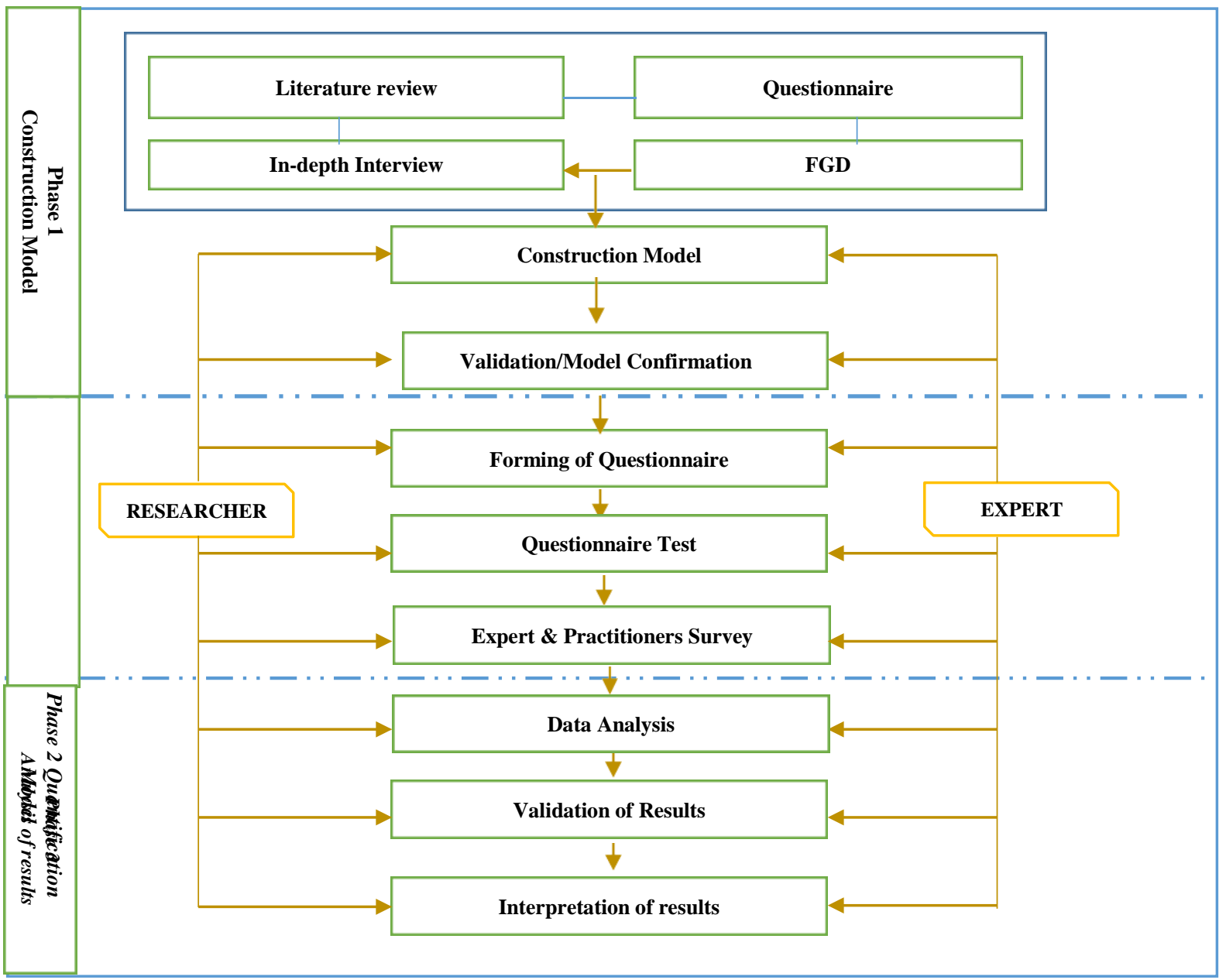

Source: (Ascarya, 2010)

a. The geometric mean is used to find out the results of the individual assessment of the respondents and determine the results of the opinions of one group. An assessment is done by calculating the geometric mean (Saaty, 2006). The question of comparison (Pairwise comparison) of the respondents will be combined so as to form a consensus. The geometric mean is a type of average calculation that shows a certain tendency or value (Rusydiana, 2012).

b. Rater Agreement is a measure showing the level of respondent ${ }^{\text {te }} \mathrm{s}$ agreement $(\mathrm{R} 1-\mathrm{Rn})$ to a problem in one cluster. The tool used in measuring the rater agreement is Kendall"s Coefficient of Concordance (W: $0<\mathrm{W} \leq 1)$. $\mathrm{W}=1$ 
indicates perfect fit. To calculate Kendall"s (W), the first step is to rank each answer and sum it up (Ascarya, 2010).
Based on the results of the research and data using the software Super Decision 2.0.8 and Microsoft Excel 2007, following are some conclusions, which are presented below:

\section{RESULTS \& DISCUSSIONS}

Table 2. General conclusions of ANP data processing results

\begin{tabular}{|c|c|c|}
\hline Aspect & $\begin{array}{l}\text { Respondent } \\
\text { NR }\end{array}$ & Ranking \\
\hline \multicolumn{3}{|l|}{$\begin{array}{l}4 \text { PILLAR OBJECTIVES OF SUSTAINABLE } \\
\text { DEVELOPMENT GOALS (SDGs) }\end{array}$} \\
\hline SOCIAL DEVELOPMENT PILAR & 0.2277 & 3 \\
\hline ECONOMIC DEVELOPMENT PILAR & 0.2419 & 2 \\
\hline ENVIRONMENTAL DEVELOPMENT PILAR & 0.2742 & $\mathbf{1}$ \\
\hline $\begin{array}{l}\text { INKLUSIF DEVELOPMENT \& } \\
\text { IMPLEMENTATION PILAR }\end{array}$ & 0.2182 & 4 \\
\hline \multicolumn{3}{|l|}{$\begin{array}{l}17 \text { GOALS OF SUSTAINABLE DEVELOPMENT } \\
\text { GOALS (SDGs) }\end{array}$} \\
\hline Goal 1. No Poverty & 0.1484 & 16 \\
\hline Goal 2. Zero Hunger & 0.1384 & 17 \\
\hline Goal 3. Good Health and Well-Being & 0.2005 & 7 \\
\hline Goal 4. Quality Education & 0.1590 & 13 \\
\hline Goal 5. Gender Equality & 0.1557 & 15 \\
\hline Goal 6. Clean Water and Sanitation & 0.1577 & 14 \\
\hline Goal 7. Affordable and Clean Energy & 0.1824 & 11 \\
\hline Goal 8. Decent Work and Economic Growth & 0.1905 & 9 \\
\hline Goal 9. Industry, Innovation and Infrastructure & 0.1680 & 12 \\
\hline Goal 10. Reduced Inequalities & 0.1880 & 10 \\
\hline Goal 11. Sustainable Cities and Communities & 0.2160 & 6 \\
\hline Goal 12. Responsible Consumption and Production & 0.2914 & 3 \\
\hline Goal 13. Climate Action & 0.2333 & 4 \\
\hline Goal 14. Life Below Water & 0.1921 & 8 \\
\hline Goal 15. Life on Land & 0.2300 & 5 \\
\hline Goal 16. Peace, Justice and Strong Institutions & 0.3999 & 2 \\
\hline Goal 17. Partnership for the Goals & 0.5866 & 1 \\
\hline \multicolumn{3}{|l|}{7 GRAND BAZNAS PROGRAMS } \\
\hline BAZNAS Health House & 0.1141 & 6 \\
\hline Smart House of the Nation Children & 0.1285 & 7 \\
\hline Zakat Community Development & 0.1732 & 1 \\
\hline Baitul Qiradh & 0.1355 & 2 \\
\hline Regeneration of 1000 Ulama & 0.1245 & 5 \\
\hline Mustahiq Service Counter & 0.1488 & 4 \\
\hline BAZNAS Disaster Response & 0.1434 & 3 \\
\hline
\end{tabular}


The overall assessment according to experts on the Relevance of the 7 Grand Programs of BAZNAS in Table 2, placing the Pillars of Environmental Development a top priority in Aspects of the 4 pillars of Sustainable Development Goals (SDGs) (0.2742).

From the above data, it is indicated that Partnership for All Development

Table 3. Overall Details of Aspects 17 Sustainable Development Goals (SDGs)

\begin{tabular}{lll}
\hline Goal 17. Partnership for the Goals & $\mathbf{0 . 5 8 6 6}$ & $\mathbf{1}$ \\
Goal 16. Peace, Justice and Strong Institutions & $\mathbf{0 . 3 9 9 9}$ & $\mathbf{2}$ \\
Goal 12. Responsible Consumption and Production & $\mathbf{0 . 2 9 1 4}$ & $\mathbf{3}$ \\
Goal 13. Climate Action & $\mathbf{0 . 2 3 3 3}$ & $\mathbf{4}$ \\
Goal 15. Life on Land & $\mathbf{0 . 2 3 0 0}$ & $\mathbf{5}$ \\
Goal 11. Sustainable Cities and Communities & $\mathbf{0 . 2 1 6 0}$ & $\mathbf{6}$ \\
Goal 3. Good Health and Well-Being & $\mathbf{0 . 2 0 0 5}$ & $\mathbf{7}$ \\
Goal 14. Life Below Water & $\mathbf{0 . 1 9 2 1}$ & $\mathbf{8}$ \\
Goal 8. Decent Work and Economic Growth & $\mathbf{0 . 1 9 0 5}$ & $\mathbf{9}$ \\
Goal 10. Reduced Inequalities & $\mathbf{0 . 1 8 8 0}$ & $\mathbf{1 0}$ \\
Goal 11. Sustainable Cities and Communities & $\mathbf{0 . 1 8 2 4}$ & $\mathbf{1 1}$ \\
Goal 9. Industry, Innovation and Infrastructure & $\mathbf{0 . 1 6 8 0}$ & $\mathbf{1 2}$ \\
Goal 4. Quality Education & $\mathbf{0 . 1 5 9 0}$ & $\mathbf{1 3}$ \\
Goal 6. Clean Water and Sanitation & $\mathbf{0 . 1 5 7 7}$ & $\mathbf{1 4}$ \\
Goal 5. Gender Equality & $\mathbf{0 . 1 5 5 7}$ & $\mathbf{1 5}$ \\
Goal 1. No Poverty & $\mathbf{0 . 1 4 8 4}$ & $\mathbf{1 6}$ \\
Goal 2. Zero Hunger & $\mathbf{0 . 1 3 8 4}$ & $\mathbf{1 7}$ \\
\hline In & &
\end{tabular}

In an overall assessment of Aspects of the Grand Program of BAZNAS, Zakat Community Development Program (0.1732) appears to be a top priority in aligning the program towards the 17 Sustainable Development Goals (SDGs). The priority sequence of the 7 Grand Programs of the next BAZNAS is occupied by Baitul Qiradh (0.1355), BAZNAS Disaster Response (0.1434), Mustahiq Service Counter (0.1488), Regeneration of 1000 Ulama (0.1245), BAZNAS Health House (0.1141) and
Objectives is the most important priority in integrating 17 Goals for Sustainable Development Goals (SDGs) to the BAZNAS program with an average rating (0.5866) with details of priority on 17 Sustainable Development Goals (SDGs) as follows:
Smart House of the Nation Children (0.1285).

The results from statistically obtained data with the consensus of experts show that the pillar of Environmental Development is the main priority in 4 pillars of Sustainable Development Goals (SDGs). In the case of this assessment, the level of agreement among the respondents is quite high with the rater agreement of $(\mathrm{W}=0.47783)$. 
Figure 5. Priority Aspects, 4 Pillars of Sustainable Development Goals (SDGs)

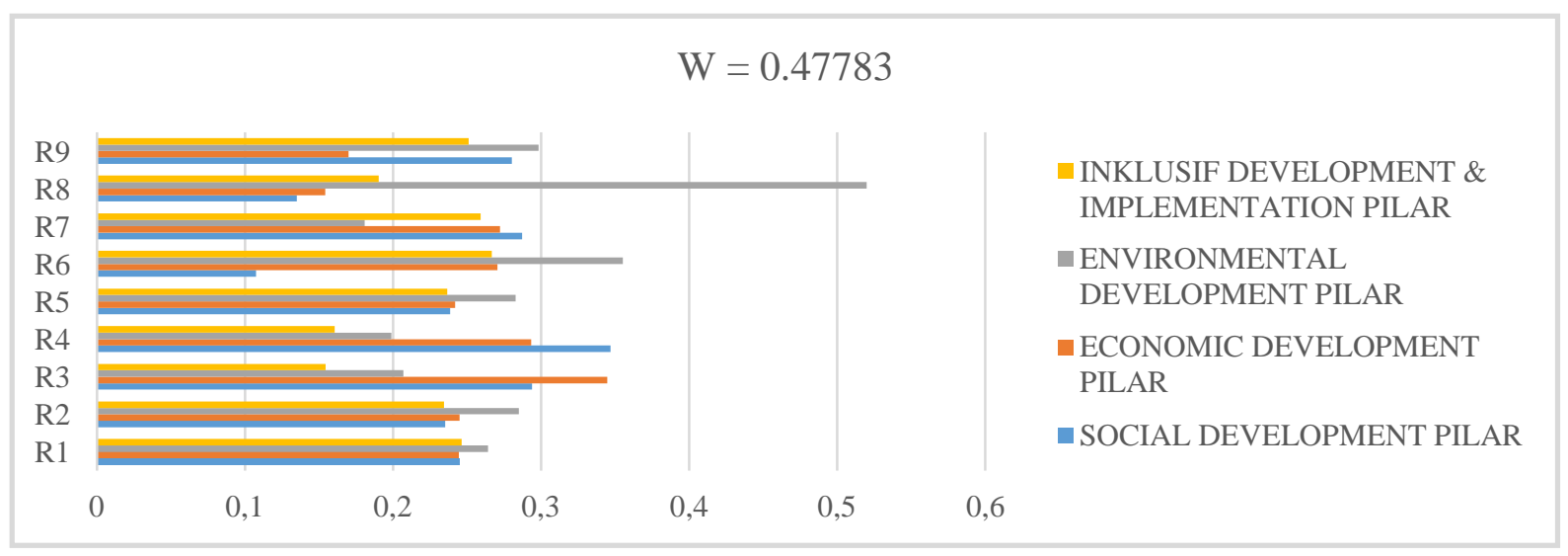

The related Sustainable Development Goals (SDGs) based on geometric mean indicate that Goals 17 ,Partnerships For All Goals" occupy the main priority in synergizing programs with the BAZNAS
Program. The priority determination among the respondents varies with the rater agreement of $(\mathrm{W}=0.00486)$ as seen in Figure 6.

Figure 6. Priorities in 17 Sustainable Development Goals (SDGs)

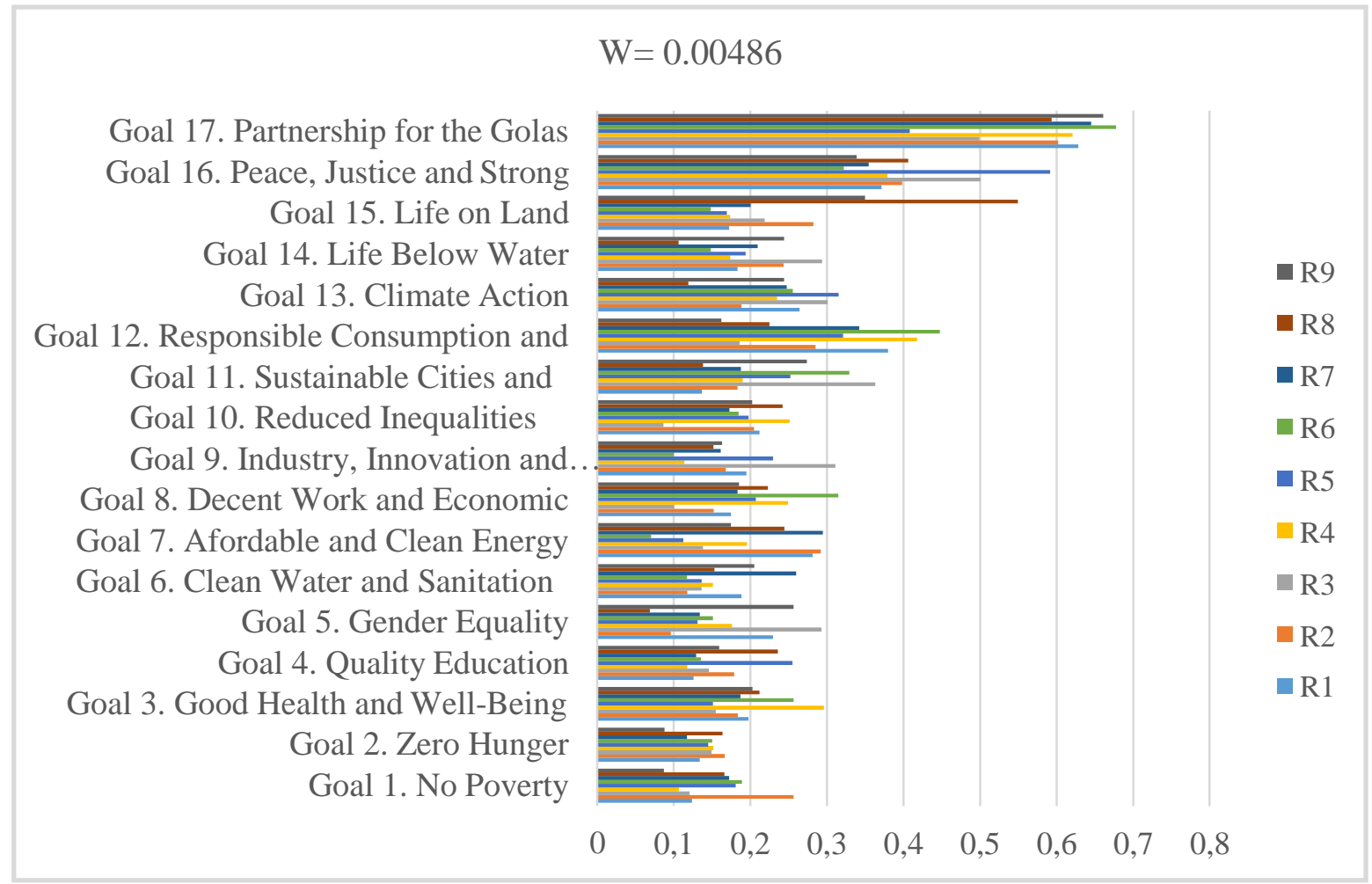


As we can see in Figure 7, the respondents coming from Academics, Indonesian Ministry of National Development Planning (BAPPENAS) and The National Board of Zakat (BAZNAS) tend to vary in response that Zakat
Community Development occupies the top priority in developing the BAZNAS Program towards Sustainable Development Goals (SDGs). This shows that the agreement level of the respondents varied $(\mathrm{W}=0.0736)$.

Figure 7. Priority Aspect of Grand Program BAZNAS

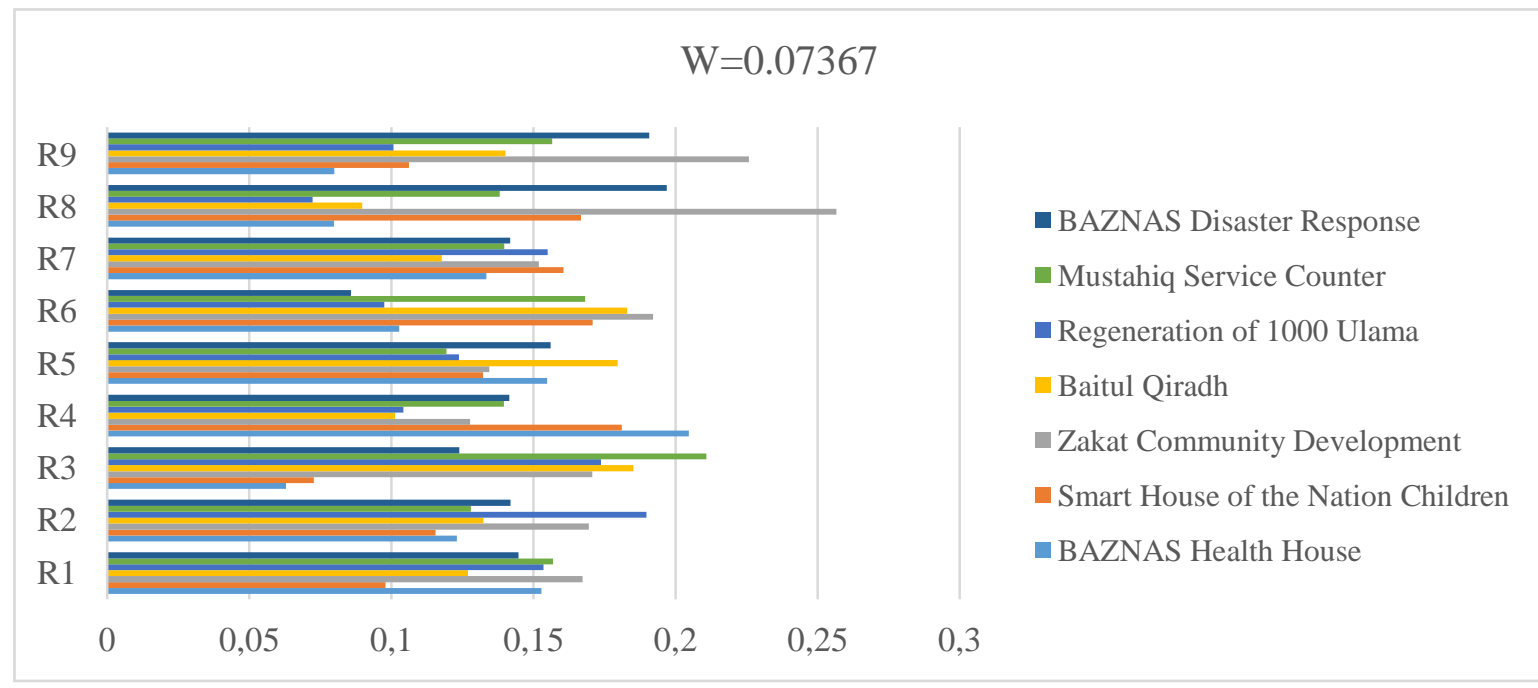

\section{CONCLUSION}

Based on the results of the data, the researcher concludes that respondents are relatively united in their opinion related to the development of The National Board of Zakat (BAZNAS) program, where its relevance has priority in the following order.

1. General conclusions based on data analysis using the Analytic Network Process (ANP) method show that the Pillars of Environmental Development having the top priority among the 4 Pillars of Sustainable Development Goals (SDGs) with an average rating of (0.2742). The Goal 17, „Partnership For All Development Goals" received top priority in the 17 Sustainable Development Goals (SDGs) in terms of synergy with 7 Grand BAZNAS Program with an average score of (0.5866). In terms of the Grand Program BAZNAS, Zakat Community Development Program is the main priority of the program in regards to 17 Goals of Sustainable Development with an average value of $(0.1732)$

2. Results from statistically obtained data with the consensus of experts show that Pillar of Environmental Development is a priority on the 4 Pillars of Sustainable Development Goals (SDGs) with a rater agreement of $(\mathrm{W}=0.47783)$.

3. Geometric mean indicates that Goals 17 „Partnership for All Goals" occupies the main priority with the rater agreement of $(\mathrm{W}=$ 0.00486).

4. In the priority assessment of the 7 Grand BAZNAS Program, the respondents tend to vary in their view as to whether Zakat Community Development occupies the top priority in developing the 
BAZNAS Program towards Sustainable Development Goals (SDGs) or not. For the National Board of Zakat (BAZNAS) Program against Sustainable Development Goals Objectives (SDGs), the rater agreement has a value of $(\mathrm{W}=0.07367)$.

\section{REFERENCES}

Al-Qur'an

Ahmed, H. (2015). On Sustainable

Development Goals and the Role of Islamic Finance. World Bank

Policy Research Working Paper 7266.

Ascarya. (2005, Januari). Analytic Network Process (ANP):

Pendekatan Baru Studi Kualitatif

Ascarya. (2005, Januari). Konsep Dasar ANP: Pendekatan Baru dalam Penelitian Kualitatif.

Ascarya. (2010). Determinan dan Persistensi Margin Perbankan Konvensional dan Syariah di Indonesia (working paper series ed., Vol. No.WP/10/04.). Pusat Pendidikan dan Studi Kebanksentralan Bank Indonesia.

Ascarya, D. Y. (2015, Juni). Mencari Solusi Rendahnya Pembiayaan Bagi Hasil di Perbankan Syariah Indonesia. 30.

Azis, I. J. (2003, November). Analytic Network Process With Feedback Influence: A New Approach to Impact Study. 2.

BAPPENAS. (2017). Draft Pedoman

Teknis Penyusunan Rencana Aksi

Tujuan Pembangunan

Berkelanjutan. Jakarta:

Kementerian PPN/Bappenas.

BAPPENAS. (2017). Prsiapan

Pelaksanaan Tujuan Pembangunan
Berkelanjutan/Sustainable

Development Goals Tahun 2016.

Booklet TPB/SDGs, Kementrian

PPN/BAPPENAS, Bidang

Kemaritiman dan Sumber Daya

Alam, Jakarta.

BAZNAS. (2016). Outlook Zakat

Indonesia 2017, 21.

Billah, M. M. (2016). Creating an EcoSustainable Community: the Role of Zakat.International Journal of Zakat, 1(1), 7.

BPS. (2016). kajian Indikator Lintas Sektor : Potret Awal Tujuan Pembangunan Berkelanjutan (Sustainable Development Goals) di Indonesia. Badan Pusat Statistik, Subdirektorat Indikator Statistik. Jakarta: Badan Pusat Statistik Indonesia.

Chapra, M. U. (1992). Islam and the Economic Challenge (Vols. Islamic Economics Series - 17). Leicester: The Islamic Foundation and The International Institute of Islamic Thought.

Hadad, I. d. (2015). Sustainable financing, industri jasa keuangan dalam pembiayaan berkelanjutan. Jakarta: PT. Elex Media Komputindo.

Hoelman, M. B. (2015). Panduan SDGs Untuk Pemerintah Daerah (Kota dan Kabupaten) dan Pemangku Kepentingan Daerah.

Kamali, M. H. (2016, Januari). Focus Islam Sustainable Development. Islam and Civilisation Renewal, 911.

Lawal, I. M. (2016, Agustus). Islamic Finance; A Tool For Realizing Sustainable Development Goals (SDG) In Nigeria. International Journal of Innovative Research and Advanced Studies (IJIRAS), 3(9) 
Malik, B. A. (2016, Januari). Philanthropy in Practice: Role of Zakat in the Realization of Justice and Economic Growth. International Journal of Zakat, 1, 74

Nouh, M. (n.d.). Sustainable Development in a Muslim Context. Retrieved from Earthcharter.org: https://earthcharter.org/invent/imag es/uploads/11\%20Manuscrip_Muh ammad.pdf (diakses pada tgl 14 Mei 2017)

Norvadewi, M. (2012). Optimalisasi Peran Zakat dalammengentaskankemiskinan di Indonesia. 74.

Nurzaman, M. S. (2017, Januari). Methodology, National Zakat Index: Framework and. (N. A. Ridho Gusti Hendharto, Ed.) Puskas Working Paper Series, 04, 3.

Rusydiana, A. D. (2012). Aplikasi Metode Analitic Network Process (ANP) Untuk Mengurai Problem

Mohamad Handi Khalifah

University of Indonesia

handikhalifah@gmail.com

Mohammad Soleh Nurzaman

University of Indonesia

dedenmsn@gmail.com

Muhammad Cholil Nafis

University of Indonesia

nafismdr@yahoo.com
Pengembangan Baitul Maal WatTamwiil (BMT) Di Indonesia. 15.

Saaty, T. L. (2006). Decision Making with the Analytic Network Process. Economic, Political, Social and Technological Applications with Benefits, Opportunities, Costs and Risks. Springer.

Saaty, T. L. (1999). Fundamentals of The Analytic Network Process.

Sadeq, A. M. (2006). Development Issues in Islam. 3

Sadiq, R. (2015). The Role of Islamic Finance in Sustainable Development. Journal of Islamic Thought and Civilization, 5(1), 47.

Waage, J. (2015, March). London International Development Centre, London Governing the UN Sustainable Development Goals: interactions, infrastructures, and institutions.

http://dx.doi.org/10.1016/ S2214$109 X \quad(15) 70112-9$ or www.thelancet.com, 3. 